\title{
Identifikasi dan Purifikasi Vitelogenin Arwana Asia: Banjar, Pinoh (Scleropages macrocephalus), Papua (Scleropages jardinii) dan Super Red (Scleropages legendrei)
}

\section{[Identification and Purification of Asian Arowana Vitellogenin: Banjar, Pinoh (Scleropages macrocephalus), Papua (Scleropages jardinii) and Super Red (Scleropages legendrei)]}

\author{
Ahmad Musa ${ }^{1 *}$, Remi Dugue ${ }^{2}$, Rina Hirnawati ${ }^{1}$, Bastiar Nur $^{1}$, Rendy Ginanjar $^{1}$, Sawung \\ Cindelaras ${ }^{1}$, Slamet Sugito ${ }^{1}$ \\ ${ }^{1}$ Balai Riset Budidaya Ikan Hias, Depok, Indonesia \\ ${ }^{2}$ Institut des Sciences de l'Evolution de Montpellier, France
}

\begin{abstract}
Arowana fish (Scleropages $s p$.) are monomorphic species, those animals that physically could not be distinguished between male and female. The research was aimed to identify and purify Vitellogenin of four variants of Asian Arowana: Banjar, Papua, Pinoh, and Super red. 12 fishes, 3 from each variant were given estradiol stimulation through toad for vitellogenin production purpose. The SDS-PAGE results expressed that there were two types of Asian Arowana vitellogenin characters, single Vtg for Arowana Banjar, Pinoh (Scleropages macrocephalus) and Super Red (Scleropages legendrei) with a molecular weight of $180 \mathrm{kDa}$ and double $\mathrm{Vtg}$ in Papuan Arowana (Scleropages jardinii) with molecular weight 180 and $110 \mathrm{kDa}$. Pure vitellogenin has been collected from 3 varieties, Banjar, Papua, and Super red with a concentration range between $0.1-0.67 \mathrm{mg} / \mathrm{mL}$. The actual concentration is believed to be greater than the measured concentration.
\end{abstract}

Keywords: Asian arowana, Scleropages sp., purification, vitellogenin.

Abstrak. Ikan arwana (Scleropages $s p$ ) merupakan spesies monomorfik, yaitu hewan yang secara fisik tidak dapat atau tidak mudah dibedakan antara jantan dan betina. Penelitian ini bertujuan untuk membandingkan karakter Vtg dari arwana Banjar, Pinoh (Sceleropages macrocephalus), Papua (Scleropages jardinii) dan Super red (Scleropages legendrei). Ikan uji yang digunakan sebanyak 3 ekor per varietas yang diberi rangsangan hormon estradiol melalui percil sebagai pakan untuk menstimulasi produksi Vitelogenin. Hasil SDS-PAGE menunjukkan bahwa terdapat dua jenis karakter vitelogenin arwana asia yaitu tunggal pada arwana Banjar, Pinoh (Scleropages macrocephalus) dan Super Red (Scleropages legendrei) dengan berat molekul $180 \mathrm{kDa}$ serta ganda pada arwana Papua (Scleropages jardinii) dengan berat molekul 180 dan $110 \mathrm{kDa}$. Telah dikoleksi Vitelogenin murni dari 3 varietas yaitu Banjar, Papua dan Super red dengan kisaran konsentrasi antara 0,1 -0,67 mg/mL. Konsentrasi aktual diyakini lebih besar dari konsentrasi terukur tersebut.

Kata Kunci: Arwana asia, Scleropages sp., purifikasi, vitelogenin.

Diterima: 23 Oktober 2020, Disetujui: 3 Desember 2020

Sitasi: Musa, A., Dugue, R., Hirnawati, R., Nur, B., Ginanjar, R., Cindelaras, S., \& Sugioto, S. (2021). Identifikasi dan Purifikasi Vitelogenin Arwana Asia: Banjar, Pinoh (Scleropages macrocephalus), Papua (Scleropages jardinii) dan Super Red (Scleropages legendrel). KOVALEN: Jurnal Riset Kimia, 7(1): 1-11.

\footnotetext{
* Corresponding author

E-mail: ahmadmusasaid@kkp.go.id 


\section{LATAR BELAKANG}

Ikan arwana (Scleropages $s p$ ) merupakan spesies monomorfik, yaitu hewan yang secara fisik tidak dapat atau tidak mudah dibedakan antara jantan dan betina berdasarkan pengamatan visual terhadap morfologinya (Chumaidi et al., 2012). Indonesia memiliki lima spesies ikan arwana, yaitu arwana super red (S. legendrel), arwana hijau (S. formosus), arwana golden ( $S$. aureus), arwana pinoh ( $S$. macrocephalus), dan arwana papua (S. jardinii) (Pouyaud et al., 2003). Selain kelima ini, juga terdapat Scleropages inscriptus dari Myanmar (Roberts, 2012), Scleropages leichardti dari Australia (Pusey et al., 2016) dan Scleropages sinensis dari Cina (Zhang \& Wilson, 2017). Khusus ikan arwana super red, konservasinya di alam sudah sangat diperhatikan karena penangkarannya telah banyak dilakukan (Kartamihardja et al., 2014)

Studi biokimia dan molekuler ikan arwana telah banyak dilakukan, termasuk untuk keragaman genetik (Austin et al., 2015; Chao et al., 2016; Ngili et al., 2015; Lavoue, 2015; Manoharan et al., 2011; Shen et al., 2014), reproduksi (Chang, 2009), pakan (Thipwong et al., 2015) dan identifikasi kelaminnya (Benjaboonyazit, 2014; Chansue et al., 2013; Esmaeili et al., 2017).

Salah satu fase pematangan gonad pada ikan betina adalah terjadinya vitelogenesis. Vitelogenesis adalah sintesis vitelogenin (Vtg) atau prekursor kuning telur yang terjadi di dalam hati. Vitelogenesis dipicu oleh adanya pengaruh hormon estrogen 17 $\beta$-estradiol (Brion et al., 2000) melalui proses fosforilasi, glikosilasi dan lipidasi di dalam hati yang kemudian menghasilkan Vtg (Parks et al., 1999). Vtg adalah glikofosfoprotein yang terdiri dari sekitar $20 \%$ lemak, terutama fosfolipid, trigliserida dan kolesterol (Tyler, 1991). Protein ini diangkut menuju ovarium oleh darah dan dimasukkan ke dalam oosit yang sedang berkembang lalu terdegradasi menjadi lipovitelin pada kuning telur (Parks et al., 1999). Vtg yang merupakan prekursor kuning telur merupakan ciri spesifik induk betina hingga bila terdeteksi pada seekor ikan, maka dipastikan ikan tersebut betina. Vtg sebagai parameter kematangan gonad telah diamati pada ikan Arapaima gigas (Chu-Koo et al., 2008) ikan kerapu (Daud Om et al., 2016) dan Sturgeon Hosu hosu (Kazemi et al., 2020) dan berhasil ditemukan perbedaan jantan dan betinanya berdasarkan kadar Vtg ini.

Stimulasi produksi Vtg menggunakan hormon estradiol pada arwana baik oral maupun injeksi menunjukkan hasil yang sama efektif (Musa \& Hirnawati, 2018). Untuk memecahkan masalah monomorfisme pada arwana dibutuhkan proses identifikasi Vtg. Identifikasi Vtg dapat dilakukan dengan metode immunoassay (Wang et al., 2017). Metode immunoassay membutuhkan adanya antigen dan antibodi (Tsukada et al., 2019). Dalam hal ini Vtg berperan sebagai antigen untuk memproduksi anti-Vtg (Caza et al., 2020).

Untuk memperoleh Vtg murni dari spesies ikan arwana maka dibutuhkan proses karakterisasi profil Vtg (Costa et al., 2016; Upadhyay et al., 2016) dari berbagai spesies ikan arwana yang kemudian dilanjutkan dengan proses purifikasi. Penelitian ini bertujuan untuk membandingkan karakter Vtg dari arwana Banjar, Papua, Pinoh dan Super red dan mempurifikasi Vtg dari arwana Banjar, Papua dan Pinoh. Hasil dari penelitian ini akan dilanjutkan untuk ke tahap produksi antibodi dan metode immunoassay lanjutan. 


\section{METODE PENELITIAN}

\section{Bahan dan Peralatan}

Ikan uji yang digunakan sebanyak 12 ekor dengan 3 ekor per varietas (Tabel 1). Bahan lain yang digunakan meliputi hormon Estradiol, etanol, Phenoxyethanol, $\mathrm{H}_{2} \mathrm{O}, 0.5 \mathrm{M}$ Tris- $\mathrm{HCl}$, $\mathrm{pH}$ 6.8, Glycerol, $10 \%$ (w/v) SDS dan mercaptoethanol, 1 \% (w/v) bromophenol blue, Bovine Serum Albumin (BSA), dan heparin.

Peralatan yang digunakan meliputi vortex, botol falcon, sentifugator, nano spektrofotometer, dan seperangkat alat Elektroforesis SDS-PAGE.

\section{Prosedur Penelitian}

Ikan uji dipelihara dalam akuarium ukuran $80 \times 40 \mathrm{~cm}$ dengan ketinggian air $20-30 \mathrm{~cm}$. Ikan uji diadaptasi selama sebulan sebelum diberikan perlakuan hormon. Masing - masing ikan uji ditempatkan pada akuarium yang berbeda untuk identifikasi. Ikan diberikan pakan percil yang telah diberi hormon ke bagian perut yang selanjutnya diberikan ke ikan sebagai pakan sebanyak 2 ekor perhari.

$250 \mathrm{mg}$ hormon Estradiol dilarutkan dalam $5 \mathrm{~mL}$ etanol absolut pada botol falcon, larutan dihangatkan pada suhu maksimal $62,5^{\circ} \mathrm{C}$ dan divortex hingga larutan berwarna bening. Larutan dibiarkan menguap hingga jenuh yaitu setelah tidak terjadi pengurangan volume akibat etanol menguap, lalu ditambahkan dengan cairan cocoa butter yang hangat hingga volume $8 \mathrm{~mL}$ lalu divortex. Setelah merata suspensi didiamkan hingga membentuk padatan. Sebelum digunakan, suspensi dihangatkan hingga mencair lalu disuntikkan secepatnya $50 \mathrm{mg} / \mathrm{kg}$ ke perut ikan langsung maupun ke percil dengan dosis hormon yang diberikan $0,1 \mathrm{~mL}$ per percil, selanjutnya percil akan diumpankan ke ikan uji sebanyak 2 ekor perhari.

Tabel 1. Data kode, nomor tag, panjang total $(\mathrm{cm})$ dan bobot $(\mathrm{g})$ ikan uji.

\begin{tabular}{cccc}
\hline $\begin{array}{c}\text { Kode/ } \\
\text { code }\end{array}$ & Nomor tag/ tag number & $\begin{array}{c}\text { Panjang total/ Total Length } \\
(\mathrm{cm})\end{array}$ & Bobot/ Weight $(\mathrm{g})$ \\
\hline B1 & O168003057 & 30,5 & 225,0 \\
B2 & O168003367 & 29,0 & 198,0 \\
B3 & O168003616 & 29,0 & 177,0 \\
P1 & 407A0B6821 & 37,5 & 440,0 \\
P2 & 146256161A & 38,0 & 444,5 \\
P3 & 1B0B005461 & 33,0 & 320,5 \\
J1 & 7F7F116130 & 34,0 & 266,0 \\
J2 & 7F7F106177 & 31,0 & 362,0 \\
J3 & 1B0B007427 & 45,0 & 820,4 \\
S1 & 1B0B005419 & 37,0 & 439,0 \\
S2 & 1B0B005411 & 37,5 & 409,2 \\
S3 & 1B0B005435 & 34,0 & 320,0
\end{tabular}

Catatan: Inisial mengacu pada spesies; B: Banjar, J: Papua, P: Pinoh dan S: Super red. Angka mengacu pada nomor ikan.

Pemingsanan ikan uji dilakukan sebelum pengukuran panjang dan bobot badan, pengambilan darah dan penyuntikan hormon. Pemingsanan dilakukan dengan menggunakan Phenoxyethanol 0,4 mL/L air. Ikan sadar beberapa menit setelah dimasukkan ke wadah yang terisi air yang diaerasi. Darah diambil dengan cara penyuntikan pada bagian pangkal ekor kemudian dimasukkan ke dalam plastik tube tipe centrifuge yang telah diberi heparin sebagai anti koagulan. Pengambilan darah dilakukan sebelum stimulasi hormon (kontrol) 
dan hari kesepuluh. Darah yang telah diambil lalu disentrifugasi dengan kecepatan 10.000 rpm selama lima menit pada suhu $4^{\circ} \mathrm{C}$. Plasma kemudian dibuat dalam alikuot dan disimpan pada suhu $-20^{\circ} \mathrm{C}$

Karakterisasi Vtg dilakukan dengan membandingkan kandungan protein plasma darah sebelum dan sesudah rangsangan hormon dengan menggunakan metode Sodium Dodecyl Sulphate - Polyacrylamide Gel Electrophoresis (SDS-PAGE) (Laemmli, 1970) yang dilakukan dengan memigrasikan sampel melalui stacking gel dan separating gel.

$5 \mu \mathrm{L}$ plasma darah dari 12 sampel ikan uji dilarutkan dalam $100 \mu \mathrm{L}$ buffer sampel (dd $\mathrm{H} 2 \mathrm{O}, 0,5 \mathrm{M}$ Tris- $\mathrm{HCl}$, pH 6,8, Glycerol, $10 \%$ $(w / v)$ SDS dan -mercaptoethanol, $1 \%(w / v)$ bromophenol blue) lalu dimasukkan ke dalam sumur gel sebanyak $10 \mu \mathrm{L}$ per sumur. Sumur yang digunakan sebanyak 14, 12 untuk sampel ikan uji dan dua untuk standar protein. Migrasi protein dilakukan selama 45 - 60 menit atau hingga sampel mencapai bagian terbawah dari gel. Gel lalu direndam dengan menggunakan larutan staining selama 2 jam lalu dibilas dengan larutan fiksatif. Pita yang terlihat pada sampel yang diberi rangsangan hormon lalu dibandingkan dengan pita sampel kontrol. Pita yang berbeda dapat dianggap sebagai Vtg. Penentuan berat molekul Vtg dilakukan melalui perbandingan dengan standar protein yang digunakan.

Purifikasi Vtg dilakukan pada varietas Banjar, Papua dan Super Red, mengingat bahwa Pinoh dan Banjar dianggap satu spesies. Purifikasi dilakukan dengan teknik SDS-PAGE menggunakan gel dengan ketebalan $1,5 \mathrm{~mm}$ untuk memisahkan protein dalam kandungan plasma darah ikan uji. Tegangan yang digunakan sebesar 150 Volt selama 45 menit. Setelah migrasi terjadi, pita yang menunjukkan Vtg kemudian dipotong lalu dimasukkan ke dalam tabung elusi untuk memisahkan protein dari gel dengan arus sebesar $10 \mathrm{~mA} /$ tabung selama 3 jam. Purifikasi Vtg dilakukan secara berulang-ulang hingga Vtg murni yang didapatkan cukup untuk digunakan sebagai antigen untuk produksi antibodi maupun pada proses ELISA. Konsentrasi Vtg murni dalam sampel dianalisis secara kuantitatif dengan pengukuran menggunakan nano spektrofotometer pada panjang gelombang 280 (Metode Protein A280). Untuk tujuan validasi Bovine Serum Albumin (BSA) digunakan sebagai standar untuk membandingkan antara konsentrasi aktual dan konsentrasi terukur (Hirnawati \& Musa, 2015).

\section{HASIL DAN PEMBAHASAN}

Dengan pemberian stimulasi hormon secara oral, ikan menunjukkan kondisi yang sehat dimana respon terhadap pakan agresif dan bergerak lincah (Musa \& Hirnawati, 2018). Setelah pengambilan darah terakhir, ikan tetap bertahan dan dapat dipelihara untuk penelitian lanjutan. Produksi Vtg dengan cara oral juga efektif karena ukuran bukaan mulut arwana yang dapat memangsa percil. Hasil pengujian menunjukkan bahwa proses produksi Vtg berhasil dilakukan. Estradiol efektif untuk merangsang Vitelogenesis dan menghasilkan banyak vitelogenin yang diproduksi pada hati ikan (Magalhães et al., 2004; Brion et al., 2000; Madsen et al., 2013; Zhong et al., 2014). Ekspresi vtg secara signifikan lebih tinggi di hati dan gonad dibandingkan dengan ekspresi di jaringan lain (Pan et al., 2019).

Hasil identifikasi berdasarkan metode SDS-PAGE pada sampel hari ke-10 masing- 
masing ikan uji menunjukkan bahwa terdapat kesamaan karakter Vtg pada Arwana Banjar, Pinoh dan Super red (Gambar 1). Berat molekul Vtg yang terukur pada ketiga varietas tersebut adalah 180 kiloDalton (kDa), sedangkan pada Arwana Papua terdapat dua jenis Vtg yang terlihat yaitu pada berat molekul 180 kDa untuk Vtg1 dan 110 kDa untuk Vtg2. Durasi ekspresi Vtg setelah pemberian estradiol ini sama pada ikan marbled flounder (Pseudopleuronectes yokohamae), black rockfish (Sebastes schlegelii) dan fat greenling (Hexagrammos otakii) (Li et al., 2018), sedangkan pada ikan Astyanax bifasciatus, Chrenicicla iguassuensis dan Geophagus brasiliensis adalah 15 hari (Yamamoto et al., 2017) begitu pula pada Rhamdia quelen (Costa et al., 2016).

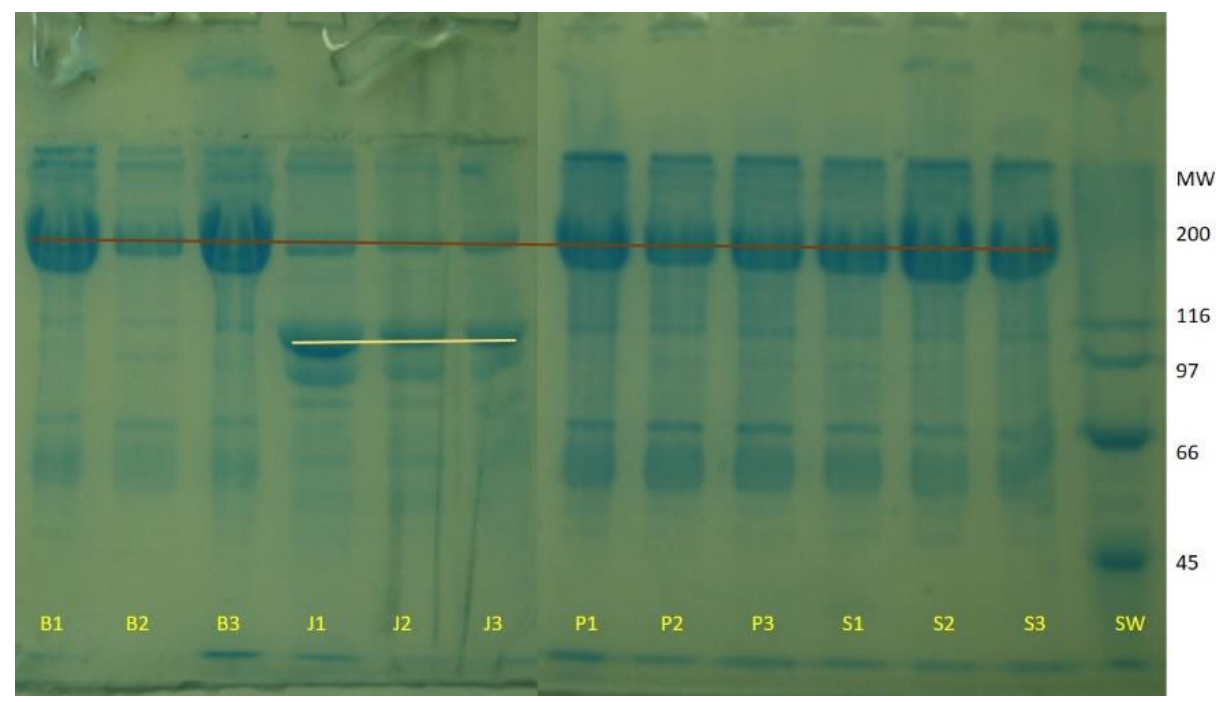

Gambar 1. Karakter Vtg empat varietas arwana. Inisial mengacu pada spesies; B: Banjar, J: Papua, P: Pinoh dan S: Super red. Angka mengacu pada angka ikan. Garis coklat mengacu pada Vtg1 and garis kuning mengacu pada Vtg2.

Vtg tunggal terdapat pada patin albino (Pangasianodon hypophthalmus) dan gurame padang (Osphronemus goramy) (Musa \& Hirnawati, 2016), marbled flounder (Pseudopleuronectes yokohamae), black rockfish (Sebastes schlegelii) dan fat greenling (Hexagrammos otakii) (Li et al., 2018), Geophagus brasiliensis (Yamamoto et al., 2017), serta Rhamdia quelen (Costa et al., 2016). Karakter Vtg Arwana Papua memiliki kesamaan dengan Arapaima gigas yang memiliki 2 Vtg yaitu Vtg 1 dan Vtg 2 (Chu-Koo et al., 2008) dengan dugaan berat molekul 180 $\mathrm{kDa}$ dan 110 kDa masing-masing. Dua jenis Vtg juga ditemukan di Rainbow Trout
(Oncorhynchus mykiss) pada berat molekul 390 dan $176 \mathrm{kDa}$ (Bon et al., 1997). Ikan ringau (Datnioides microlepis) memiliki dua jenis Vtg dengan molekul berat 180 dan 110 kDa (Musa, 2016) dan Clarias batrachus memiliki dua Vtg dengan berat molekul 95 dan $67 \mathrm{kDa}$ (Mahapatra et al., 2017).

Belum diketahui apakah perbedaan karakter Vtg antara Arwana Papua dan ketiga varietas lainnya memiliki korelasi dengan perbedaan pendapat tentang spesiasi Arwana Asia, di mana Pouyaud et al. (2003) mengklasifikasikan bahwa arwana asia di Indonesia terdiri dari lima spesies, sedang Yue et al., (2002) dan Mohd-Shamsudin et al., (2011) 
tetap menganggap bahwa hanya ada dua spesies di arwana asia yaitu Scleropages formosus dan Scleropages jardinii.

Hasil purifikasi menunjukkan bahwa telah berhasil didapatkan Vtg murni dari tiga varietas arwana yaitu Banjar, Papua dan Super Red (Gambar 2). Keberhasilan purifikasi terlihat dari adanya pita tunggal tipis dan jelas pada setiap sumur. Purifikasi Vtg ikan telah banyak dilakukan untuk tujuan immunoassay seperti pada Alburnus tarichi (Oguz et al., 2019), Giant grouper (Epinephelus lanceolatus) (Daud Om et al., 2016), Mugil cephalus (Amano et al., 2019), Heteropneustes fossilis (Biswas, 2018) dan Oryzias melastigma (Yi et al., 2018) serta banyak ikan lainnya.

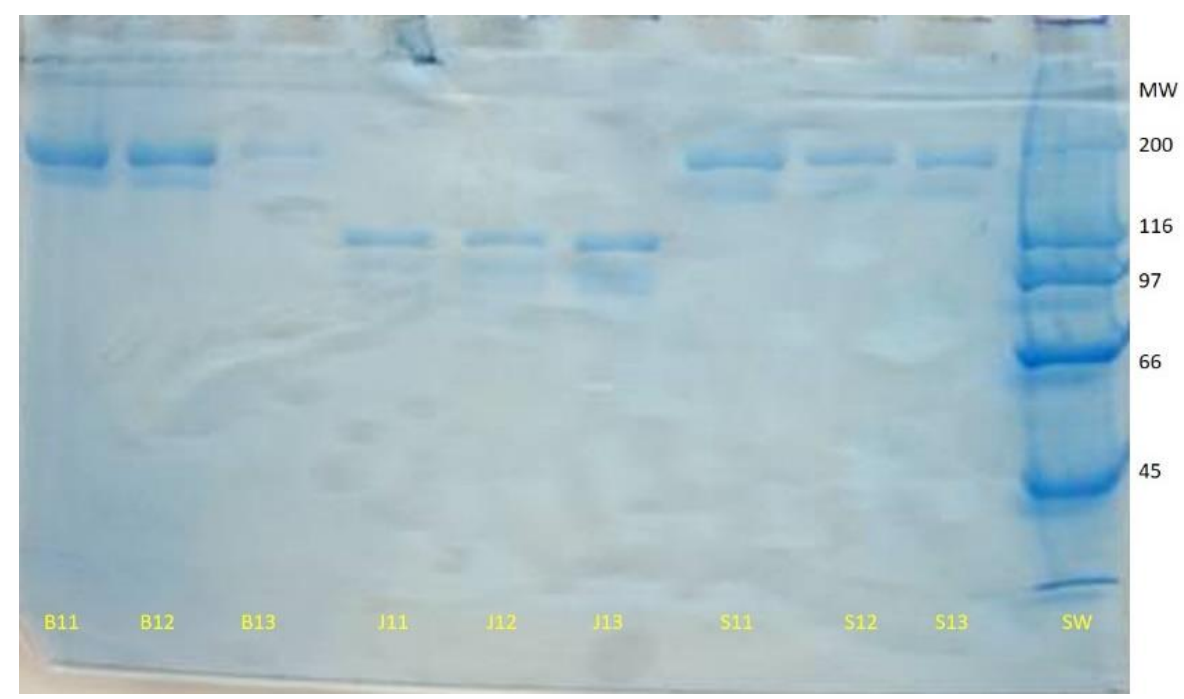

Gambar 2. Uji kualitas hasil pemurnian dari tiga varietas arwana. Inisial mengacu pada spesies ; B : Banjar, J : Papua dan S : Super red. Angka mengacu pada nomor ikan

Berdasarkan kualitas hasil pemurnian pada Gambar 2 maka kadar Vtg yang berhasil dipurifikasi ditentukan melalui uji kuantifikasi. Hasil uji kuantifikasi dengan metode protein A280 pada standar BSA menunjukkan bahwa konsentrasi terukur jauh lebih rendah dibanding konsentrasi aktual (Hirnawati \& Musa, 2015). $\mathrm{Hal}$ ini menunjukkan bahwa meskipun pembacaan kecil, konsentrasi aktual Vtg dalam sampel hasil purifikasi dapat lebih tinggi dari konsentrasi terukur (Tabel 2).

Penggunaan metode protein A280 ini memiliki banyak keuntungan di antaranya adalah penggunaan sampel yang sedikit $(2 \mu \mathrm{L})$, tidak perlu mengganti pelarut sampel dan waktu yang lebih cepat karena tidak perlu mencampur dengan pereaksi tertentu (Anonim, 2008).
Tabel 2. Kode sampel dan konsentrasi terukur $(\mathrm{mg} / \mathrm{mL})$ sampel hasil purifikasi.

\begin{tabular}{cc}
\hline Kode sampel & $\begin{array}{c}\text { Konsentrasi terukur } \\
(\mathrm{mg} / \mathrm{mL})\end{array}$ \\
\hline B11 & 0,67 \\
B12 & 0,65 \\
B13 & 0,33 \\
J11 & 0,40 \\
J12 & 0,10 \\
J13 & 0,48 \\
S11 & 0,51 \\
S12 & 0,11 \\
S13 & 0,42
\end{tabular}

Catatan: Inisial mengacu pada spesies dan standar; B: Banjar, J: Papua dan S: Super red. Angka mengacu pada nomor ikan.

Metode protein A280 juga sangat bagus untuk pengukuran protein murni yang telah melalui proses purifikasi (Anonim, 2008). Metode protein A280 telah dimanfaatkan untuk 
pengukuran Xylanase dari Aspergillus ficuum (Lu et al., 2008), protein imunogenik Mycobacterium sp pada ikan mas (Rahmaningsih \& Yanuhar, 2012) serta Vtg dari ovarium Amphioxus (Sun \& Zhang, 2001). Metode A280 juga digunakan untuk pengukuran konsentrasi protein pada bisa (Bocian et al., 2020), protein monoklonal canine sera (Harris et al., 2019) bahkan untuk protein rekombinan dalam pengujian Covid-19 (Johari et al., 2020).

Konsentrasi Vtg murni terukur yang berhasil diperoleh dari proses purifikasi berkisar dari 0,1 sampai $0,67 \mathrm{mg} / \mathrm{mL}$. Vtg yang diperoleh dapat dimanfaatkan untuk memproduksi antibodi proses imunoassay yang kedepannya sangat berguna untuk proses deteksi Vtg baik secara kualitatif maupun kuantitatif (Li et al., 2018).

Permasalahan di arwana yang bersifat monomorfik dengan diperolehnya Vtg ini akan dapat dipecahkan dan didapatkan jalan keluarnya. Di mana pada spesies lain, Vtg juga telah banyak digunakan sebagai indikator pembeda kelamin seperti pada Arapaima gigas (Chu-Koo et al., 2008), Giant Grouper Epinephelus lanceolatus (Daud Om et al., 2016), Yellowfin Seabream Acanthopagrus latus (Negintaji et al., 2019) dan lainnya.

Meskipun pada ikan jantan juga terkadang terdeteksi adanya vitellogenin (Pan et al., 2019), namun hal ini diduga disebabkan oleh adanya gangguan dari senyawa estrogen yang terekspos ke lingkungan (endocrine disruptor compounds) seperti yang teramati pada beberapa ikan di sungai Iguacu, Brazil (Yamamoto et al., 2017), ikan rainbow trout di Park City, Utah, Amerika Serikat (Franco, 2020) dan brown trout di sungai Liri, Italia (Zezza,
2020). Dalam keadaan normal, Vtg hanya terdapat pada ikan betina (Li \& Zhang, 2017).

Dengan diperolehnya isolat $\mathrm{Vtg}$ yang murni, maka proses immunoassay dapat dilanjutkan ke tahap produksi antibodi untuk selanjutnya dapat didesain metode interaksi Vtg dengan anti-Vtg baik melalui western blot (Oğuz et al., 2019), ELISA (Li et al., 2018) maupun dot blot (Nanthanawat \& Prasatkaew, 2018) dengan hasil ini diharapkan kelamin ikan arwana dapat ditentukan secara akurat. Jika kelamin ikan arwana dapat dibedakan maka akan memudahkan proses budidaya secara efektif (Medipally et al., 2016). Pemasangan induk jantan dan betina dengan rasio tertentu dapat dilakukan untuk memudahkan proses pemijahan (Yue et al., 2020). Pemijahan ikan arwana dengan rasio kelamin jantan dan betina yang efektif tentu akan membuat usaha budidaya arwana ini menjadi lebih efisien dengan produktitifas yang tinggi.

\section{KESIMPULAN}

Terdapat dua jenis karakter vitelogenin arwana asia yaitu tunggal pada arwana Banjar, Pinoh (Scleropages macrocephalus) dan Super Red (Scleropages legendrei) dengan berat molekul $180 \mathrm{kDa}$ serta ganda pada arwana Papua (Scleropages jardinii) dengan berat molekul 180 dan 110 kDa. Telah dikoleksi Vitelogenin murni dari 3 varietas yaitu Banjar, Pinoh dan Papua dengan kisaran konsentrasi antara 0,1 - 0,67 $\mathrm{mg} / \mathrm{mL}$. Konsentrasi aktual diyakini lebih besar dari konsentrasi terukur tersebut.

\section{UCAPAN TERIMA KASIH}

Penulis mengucapkan terima kasih pada Marjono dan Angga Gumelar atas 
partisipasinya dalam membantu pelaksanaan sampling.

\section{DAFTAR PUSTAKA}

Amano, H., Kotake, A., Hiramatsu, N., Fujita, T., Todo, T., Aoki, J. Y., ... \& Hara, A. (2019). Development of specific chemiluminescent immunoassays for three subtypes of vitellogenin in grey mullet (Mugil cephalus). General and comparative endocrinology, 271: 30-38.

Anonim, (2008), NanoDrop 1000 Spectrophotometer V3 . 7 User' $s$ Manual. Thermo Scientific

Austin, C.M., Tan, M.H., Croft, L.J., Hammer, M.P., Gan, H.M. (2015). Whole genome sequencing of the Asian arowana (Scleropages formosus) provides insights into the evolution of ray-finned fishes. Genome Biol Evol. 7(10): 28852895. doi:10.1093/gbe/evv186

Benjaboonyazit, T. (2014) Systematic approach to arowana gender identification problem using algorithm of inventive problem solving (ARIZ). Eng J. 18(2):13-28.

doi:10.4186/ej.2014.18.2.13

Biswas, A. (2018). Development of Vitellogenin ELISA and study of vitellogenin synthesis of Triploid Heteropneustes fossilis (Bloch). IJRAR, 6(1):1175-1184.

Bocian, A., Sławek, S., Jaromin, M., Hus, K. K., Buczkowicz, J., Łysiak, D., ... \& Legáth, J. (2020). Comparison of Methods for Measuring Protein Concentration in Venom Samples. Animals, 10(3): 448.

Bon, E., Barbe, U., Nuñez, R.J., Cuisset, B., Pelissero, C., Sumpter, J.P., Le Menn, F. (1997). Plasma vitellogenin levels during the annual reproductive cycle of the female rainbow trout (Oncorhynchus mykiss): Establishment and validation of an ELISA, Comp Biochem Physiol, 117 B: 75-84.

Brion, F., Rogerieux, F., Noury, P., Migeon, B., Flammarion, P., Thybaud, E., \& Porcher, J.M. (2000). Two-step purification method of vitellogenin from three teleost fish species: rainbow trout (Oncorhynchus mykiss), gudgeon (Gobio gobio) and chub (Leuciscus cephalus). J Chromatography, B.737: 312.
Caza, J., Fernández, R., Arias, M. T., Muñoz, D., Tirado, J. O., Manjunatha, B., \& Kundapur, S. I. (2020). The Development, Purification and Characterization of Anti-Vitellogenin Antibodies Raised in Hens (Gallus gallus domesticus) Against Tilapia (Oreochromis niloticus) Vitellogenin Protein. Journal of Microbiology, Biotechnology and Food Sciences, 9(4): 1165-1168.

Chang, K.W. (2009) Molecular analysis of the breeding biology of the Asian arowana (Scleropages formosus) [PhD thesis]. National University of Singapore

Chansue, N., Tangtrongpiros, J., Sermwatanakul, A., Haetrakul, T., Jongcheranjai, M., Kiesslich, J., Jantapanon, T.K., Anekthanakul, K. (2013). Asian arowana (Scleropages formosus) sex determination using different methods. Acad. Confer. Fisher. 40:137-150.

Chao, B., Hu, Y., Ravi, V., Kuznetsova, IS., Shen, X., Mu, X., Sun, Y., You, X., et al. (2016). The Asian arowana (Scleropages formosus) genome provides new insights into the evolution of an early lineage of teleosts. Sci. Rep. $6: 24501$

Chu-Koo, F., Dugue R., Aguilar M.A., Daza A.C., Bocanegra, F.A., Veintemilla, C.C., Duponchelle, F., Renno, J.F., Tello, S., Nunez, J. (2008). Gender determination in the Paiche or Pirarucu (Arapaima gigas) using plasma vitellogenin, 17bestradiol, and 11-ketotestosterone levels, Fish Physiol Biochem., 35(1): 125-136. doi:10.1007/s10695-008-92118.

Chumaidi, C., Priyadi, A., Ginanjar, R., \& Sugiarti, L. (2012). Ciri Kelamin Sekunder Pada Arwana Silver (Sclerophages macrocephalus) Varietas Pinoh. Jurnal Riset Akuakultur, 7(2): 221-229.

Costa, D. D. M., Bozza, D. A., Rizzo, L. E., Garcia, J., Costa, M. D. M., \& de Oliveira Ribeiro, C. A. (2016). Characterization, specificity and sensibility of produced anti-Rhamdia quelen vitellogenin in Brazilian fish species. Fish physiology and biochemistry, 42(6): 1721-1732.

Daud Om, A., Jasmani, S., Sung, Y.Y., Bolong, A.A. (2016). Use of Vitellogenin as Biomarker Indicator in Sex Identification of Giant Grouper (Epinephelus 
lanceolatus). Poult Fish Wildl Sci 4: 163. doi:10.4172/2375-446X.1000163

Esmaeili, C., Heng, L.Y., Chiang, C.P., Rashid, Z.A., Safitri, E., Marugan, R. (2017). A DNA biosensor based on kappacarrageenan-polypyrrole-gold nanoparticles composite for gender determination of arowana fish (Scleropages formosus). Sens. Actuator B-Chem.242:616-624.

doi:10.1016/j.snb.2016.11.061

Franco, M. E., Stroski, K. M., Sims, J. L., Burket, S. R., Ashcroft, C., Luers, M., ... \& Lavado, R. (2020). Plasma Vitellogenin Reveals Potential Seasonal Estrogenicity in Fish from On-Site Wastewater Treatment Systems in SemiArid Streams Influenced by Snowmelt. Bulletin of Environmental Contamination and Toxicology, 105(5): 692-698.

Harris, A. D., Rout, E., Avery, A., Bolte, D., Belling-Kelly, E., \& Moore, A. R. (2019). Validation and method comparison of the use of densitometry to quantify monoclonal proteins in canine sera. Veterinary clinical pathology, 48: 78-87.

Hirnawati, R. \& Musa, A. (2015). Penentuan Konsentrasi Vitelogenin Hasil Purifikasi Dengan Metode DC Protein Assay Dan Protein A280. Prosiding Forum Inovasi Teknologi Akuakultur 2015. ISBN 978979-789-049-0.

Johari, Y. B., Jaffé, S. R., Scarrott, J. M., Johnson, A. O., Mozzanino, T., Pohle, T. H., ... \& Tee, K. L. (2020). Production of Trimeric SARS-CoV-2 Spike Protein by $\mathrm{CHO}$ Cells for Serological COVID-19 Testing. Biotechnology and bioengineering.

Kartamihardja, E. S., Umar, C., \& Aisyah, A. (2014). Pembelajaran Dari Pengelolaan dan Konservasi Sumberdaya Ikan Arwana Merah (Scleropages formosus, Muller and Schlegel, 1844) Berbasis Masyarakat di Danau Empangau, Kalimantan Barat. Jurnal Kebijakan Perikanan Indonesia, 6(2): 65-74.

Kazemi, R., Yarmohammadi, M., Hallajian A., \& Tizkar B. (2020). Determination of gender and sexual maturity stages of reared great sturgeon (Huso huso) using blood plasma sex steroid ratios. Iranian Journal of Fisheries Sciences. 19(4): 2185-2198.

Laemmli, U.K., (1970), Cleavage of structural proteins during the assembly of the head of bacteriophage T4, Nature, 227(5259): 680-685.

Lavoue, S. (2015). Testing a time hypothesis in the biogeography of the arowana genus Scleropages (Osteoglossidae). J Biogeogr. 42(12):2427-2439. doi:10.1111/jbi.12585

Li, H., \& Zhang, S. (2017). Functions of vitellogenin in eggs. In Oocytes (pp. 389401). Springer, Cham.

Li, Y., Wang, J., Zheng, M., Zhang, Y., \& Ru, S. (2018). Development of ELISAs for the detection of vitellogenin in three marine fish from coastal areas of China. Marine pollution bulletin, 133: 415-422.

Lu, F., Lu, M., Lu, Z., Bie, X., Zhao, H., \& Wang, $Y$. (2008). Purification and characterization of xylanase from Aspergillus ficuum AF-98. Bioresource Technology, 99(13): 5938-5941. http://doi.org/10.1016/i.biortech.2007.10 .051

Madsen, L.L., Korsgaard, B., Pedersen, K.L., Bjerregaard, L.B., Aagaard, T., Bjerregaard, P. (2013). Vitellogenin as biomarker for estrogenicity in flounder Platichthys flesus in the field and exposed to $17 \alpha$-ethinylestradiol via food and water in the laboratory. Mar. Environ. Res. 92: 79-86. doi:10.1016/j.marenvres.2013.09.002.

Magalhães, I., Ledrich, M.L., Pihan, J.C., Falla, J. (2004). One-step, non-denaturing purification method of carp (Cyprinus carpio) vitellogenin, J Chromatography B., 799 (1): 87-93.

Mahapatra, S., Kabita, S., Bhattacharya, D., Sarkar, S., Juin, S. K., Maitra, S., \& Nath, P. (2017). Purification and development of ELISAs for two forms of vitellogenin in Indian walking catfish, Clarias batrachus (L.). Fish physiology and biochemistry, 43(2), 477-491.

Manoharan, B., Sulaimen, Z., Omar, F., Othman, R., Mohamed, S., Bhassu, S. (2011). Isolation and characterization of novel microsatellite markers in commercial selected golden Malaysian arowana fish, Scleropages formosus (Osteoglossidae). Genet Mol Res. 10(2): 712-716. doi:10.4238/vol10-2gmr944

Medipally, S.R., Yusoff, F.M., Sharifhuddin, N., Shariff, M. (2016) Sustainable aquaculture of Asian arowana - a review. J. Environ. Biol. 37(4 Spec No):829-838. 
Mohd-Shamsudin, M. I., Fard, M. Z., Mather, P. B., Suleiman, Z., Hassan, R., Othman, R. Y., \& Bhassu, S. (2011). Molecular characterization of relatedness among colour variants of Asian Arowana (Scleropages formosus). Gene, 490(12): 47-53.

Musa, A., \& Hirnawati, R., (2016). Uji Spesifisitas Anti-Vitelogenin Ikan Gurami Padang (Osphronemus goramy) dan Patin Albino (Pangasianodon hypophthalmus), (Belum dipublikasi)

Musa, A., \& Hirnawati, R., (2018), The Effectivity of Arowana Pinoh (Scleropages macrocephalus) Vitellogenin Production using Estradiol Stimulation by Injection and Oral in Proceedings of The 5th International Conference On Research, Implementation and Education of Mathematics and Sciences (5th ICRIEMS): Revitalizing Research And Education On Mathematics And Science For Innovations And Social Development (pp. C-19-C-24). FMIPA Universitas Negeri Yogyakarta,Yogyakarta ISBN 978-602-74529-3-0.

Musa, A. (2016). Uji Koaglutinasi untuk Deteksi Vitelogenin dan Penentuan Kelamin Ikan Ringau (Datnioides microlepis), Thesis, Pasca Sarjana IPB, Bogor.

Nanthanawat, P., \& Prasatkaew, W. (2018). Development of Dot Blot Technique for Detection of Vitellogenin as a Biomarker of Endocrine Disrupting Chemicals. Burapha Science Journal (วารสาร วิทยาศาสตร์บรพา), 23(3): 1448-1457.

Negintaji, A., Safahieh, A., Zolgharnein, H., \& Matroodi, S. (2019). Vitellogenin Gene Expression and Sex Steroid Levels as Biomarkers in Yellowfin Seabream (Acanthopagrus latus) Exposed to Bisphenol-A. Iranian Journal of Toxicology, 13(1): 27-33.

Ngili, Y., Lantang, D., Ubyaan, R., Palit, E.I.Y. (2015). Mitochondrial DNA genetic diversity of arowana fish local variants on the D-loop hypervariable region: Study in the southern region of Papua-Indonesia. Der Pharma Chem. 7:223-228.

Oğuz, E. K., Özdemir, K., Ünal, G., \& Oğuz, A. R. (2019). Polyclonal antibody-based immunoassay of vitellogenin in Van fish (Alburnus tarichi). International Journal of Environmental Health Research, 1-12.
Pan, X., Liu, Y., Zhou, K., Mu, X., Zheng, S., Liu, C., Hu, Y. (2019). Tissue expression and bioinformatics analysis of the vitellogenin gene of Asian arowana (Scleropages formosus). J. Appl. Ichthyol. 35:970-977.

Parks, L.G., Cheek, A.O., Denslow, N.D., Hepell, S.A., McLachlan, J.A., LeBlanc, G.A., \& Sullivan, C.V. (1999). Fathead minnow (Pimephales promelas) vitellogenin: purification, characterization andquantitative immunoassay for the detection of estrogeniccompounds, Comp Biochem Physiol C., 123: 113125.

Pouyaud, L., \& Teugels, G. G. (2003). The different colour varieties of the Asian arowana Scleropages formosus (Osteoglossidae) are distinct species: morphologic and genetic evidences. Cybium, 27(4): 287-305.

Pusey, B. J., Fisher, C., \& Maclaine, J. (2016). On the nature of Scleropages leichardti Günther, 1864 (Pisces: Osteoglossidae). Zootaxa, 4173(1): 75-84.

Rahmaningsih, S., \& Yanuhar, U. (2012). Identifikasi Protein Imunogenik Mycobacterium sp pada Ikan Mas (Cyprinus carpio). Prosiding Seminar Nasional Tahunan IX Hasil Penelitian Perikanan dan Kelautan, 14 Juli 2012 Penyakit lkan \& Lingkungan ( PL-13) : 1-8.

Roberts, T.R. (2012) Scleropages inscriptus, a new fish species from the Tananthayi or Tenasserim River basin, Malay Peninsula of Myanmar (Osteoglossidae: Osteoglossiformes). Aqua International Journal of Ichthyology, 18: 113-118.

Sun, X., \& Zhang, S. (2001). Purification and characterization of a putative vitellogenin from the ovary of amphioxus (Branchiostoma belcheri tsingtaunese). Comparative Biochemistry and Physiology - B Biochemistry and Molecular Biology, 129(1): 121-127.

Shen, X.Y., Kwan, H.Y., Thevasagayam, N.M., Prakki, S.R.S., Kuznetsova, I.S., Ngoh, S.Y., Lim, Z., Feng, F., Chang, A., Orban, L., et al. (2014). The first transcriptome and genetic linkage map for Asian arowana. Mol Ecol Resour. 14(3):622635. doi:10.1111/1755-0998.12212

Sun, X., \& Zhang, S. (2001) Purification and characterization of a putative vitellogenin from the ovary of amphioxus 
(Branchiostoma belcheri tsingtaunese). Comparative Biochemistry and Physiology - B Biochemistry and Molecular Biology, 129(1): 121-127.

Thipwong, S., Banyen, S., Mahasawad, J. (2015). Appropriate weaning period of Asia arowana Scleropages formosus (Schlegel and Muller, 1844) by replacing live feed with pelleted feed. Thai Fish. Gazette. 8:1-28.

Tsukada, K., Tsunashima, K., Jinno, K., Hiramatsu, B., Takeuchi, S., Fujimoto, K., ... \& Saari, M. M. (2019). Using magnetic field gradients to shorten the antigen-antibody reaction time for a magnetic immunoassay. IEEE Transactions on Magnetics, 55(7): 1-5.

Tyler, C. R., (1991), Vitellogenesis in Salmonids, Proceedings of the Fourth International Symposium on the Reproductive Physiology of Fish, (University of East Anglia Press, Norwich).

Upadhyay, S. K., Singh, H., Dixit, S., Mendu, V., \& Verma, P. C. (2016). Molecular characterization of vitellogenin and vitellogenin receptor of Bemisia tabaci. PloS one, 11(5), e0155306.

Wang, J., Zhang, Z., Zhang, X., Ru, S., \& Dong, Y. (2017). Development of an immunosensor for quantifying zebrafish vitellogenin based on the Octet system. Analytical Biochemistry, 533: 60-65.

Yamamoto, F. Y., Garcia, J. R. E., Kupsco, A., \& Ribeiro, C. O. (2017). Vitellogenin levels and others biomarkers show evidences of endocrine disruption in fish species from Iguaçu River-Southern Brazil. Chemosphere, 186: 88-99.

Yi, X., Li, C., Zhong, X., \& Gong, Y. (2018). Development of a lipovitellin-based sandwich ELISA for determination of vitellogenin in the marine medaka Oryzias melastigma. Chemosphere, 197: 477-484.

Yue, G. H., Chang, A., Yuzer, A., \& Suwanto, A. (2020). Current Knowledge on the Biology and Aquaculture of the Endangered Asian Arowana. Reviews in Fisheries Science \& Aquaculture, 28(2): 193-210.

Yue, G., Li, Y., Chen, F., Cho, S., Lim, L. C., \& Orban, L. (2002). Comparison of three DNA marker systems for assessing genetic diversity in Asian arowana
(Scleropages

Electrophoresis, 23(7-8):1025-1032.

formosus).

Zezza, D., Bisegna, A., Angelozzi, G., Merola, C., Conte, A., Amorena, M., \& Perugini, M. (2020). Impact of endocrine disruptors on vitellogenin concentrations in wild brown trout (Salmo trutta trutta). Bulletin of Environmental Contamination and Toxicology, 105(2): 218-223.

Zhang J., \& Wilson, M. (2017) First complete fossil Scleropages (Osteoglossomorpha). Vertebr PalAsiat. 55:1-23.

Zhong, L., Yuan, L., Rao, Y., Li, Z., Zhang, X., Liao, T., Xu, Y., Dai, H. (2014). Distribution of vitellogenin in zebrafish (Danio rerio) tissues for biomarker analysis. Aquat. Toxicol. 149: 1-7. doi:10.1016/j.aquatox.2014.01.022 